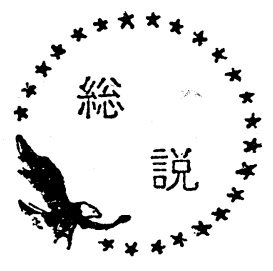

1. まえがき

燃焼炎の形状や構造は燃焼器・バーナ等の形状と寸 法あるいは燃料・酸化剤の種類やその流量条件によっ てさまざまに変化するが，そのうちで然燒装置の目的 達成上好ましくない諸現象を不安定燃焼あるいは火炎 の不安定現象と呼んでいる。火炎の吹き消光之振動然 焼はその一例である。本稿では，この二つの現象を中 心に不安定然焼と騒音についてまず概説し，ついで騒 音の主原因となり易い振動燃焼をとりあげてやや詳し く述べる。

\section{2. 不安定燃焼と吹き消え}

不安定燃焼の範ちゅうに属すると考えられる諸現象 を表 1 にまとめて示した。このうち周期的現象につい ては次節で述べる。非周期的現象は炉内の少なくとも 一部では燃燒が生じているような局部的不安定と不安 定が火炎全体におよぶいわゆる吹き消えとに区分され る。吹き消えは，それが発生すると燃焼装置がその目 的を果せなくなる点で最も重要な不安定現 象である が，吹き消えがいかなる機構により生じるかについて は不明の点が多い。吹き消えの様式やその限界は燃焼 様式によって異るので，ここでは数例を紹介するにと どめる。

\section{表 1 不安定燃焼}

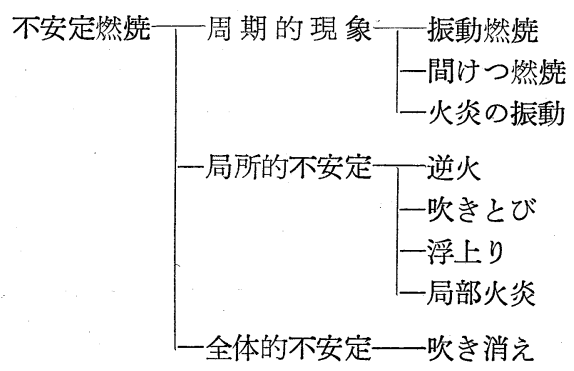

2.1 吹き消え

\section{1 .1 バーナ予混合炎}

予混合気濃度が化学当量濃度に近い場合には, 吹き 消えは吹きとびと同時に生じる。この吹きとび限界は
京都大学工学部 鈴 木 健二郎

逆火限界を整理する場合と同様に，バーナ出口壁近傍 の混合気速度勾配を用いて整理すると良い結果が得ら れる場合がある。しかし一般には基底部火炎が平面火 炎でないことの効果, 予混合気と周囲気体との混合お よびそれに伴う流れ場の変化等が影響する1)。一方然 料濃度が過濃な場合には吹きとびが生じても安定な浮 上り炎が形成され得るため吹き消えはこの浮上り炎が 不安定となって発生する。この場合の吹き消えを起す 限界予混合気噴出速度はかなり高い值になる。

\section{1 .2 保炎器を用いる高速予混合炎}

高速の予混合炎を保持するためにさまざまな形状の 保炎器が使用される。この火炎の吹き消え限界は保炎 器後方の循環流領域を均一にかくはんされた燃焼器と 見なして，燃焼負荷に対応するパラメー夕を用いて整 理すると良い結果が得られるとされている。この整理 手法は旋回により生じる循環流域内火炎 ${ }^{2}$ や，より実 際のガスタービン燃焼器に近い模型燃焼器内火炎の吹 き消え限界 ${ }^{33}$ 対しても応用が試みられている。しか し, 循環流域内の燃焼機構は一般に仮定のごとく単純 でないことを承知しておく必要がある。

\section{1 .3 バーナ拡散炎 ${ }^{4)}$}

燃料が静止空気中に噴射される場合は燃料が過濃な 予混合炎と同じであり，空気を予混合すると限界燃料 噴出速度は低下する。空気が燃料と同一方向に流れる 場合 ${ }^{4)}$ 飞は限界空気流速が重要となる。燃料噴出速度 が比較的小さい範囲では，吹き消えは吹きとびと同時 に起り, この限界空気流速はバーナの径, リム厚の減 少につれて低くなり，空気を予混合すると高くなる。 また, この限界空気流速は然料噴出速度を増すと低下 するが，ある燃料噴出速度以上では吹きとびを起して も安定な浮上り炎が形成されるようになる。この領域 での限界空気流速は空気を予混合するとかえって低下 するが，バーナの形状や燃料噴出資度にはほとんど依 存しない。

\section{1 .4 自己再循環方式の噴霧燃焼炎 ${ }^{5}$}

この型式の火炎は $\mathrm{NO}_{x}$ 排出量を低減するために利 用される。空気霧化式バーナを用いる噴霧燃焼炎では 
燃料霧化用の空気噴流が高速であるため燃焼器壁近傍 に循環渦が生じる。この循環渦により保炎される噴霧 燃焼炎の吹き消え限界は主に綜合空燃比に依存し，燃 料・空気の各流量には独立に著しく依存しないといら 特徴がある。したがって空燃比を適切に保つかぎりは かなり高い燃焼負荷が達成できる。

以上典型的な二，三の吹き消え限界例を紹介した がこの限界はつぎに述べるように振動然焼の発生によ って著しい影響を受ける。

2.2 吹き消え限界への振動燃焼の影響4)5

図 1 は2.1.3 で述べた吹き消え限界の測定例であ る。実線と破線は限界空気流速を示していて, 曲線の

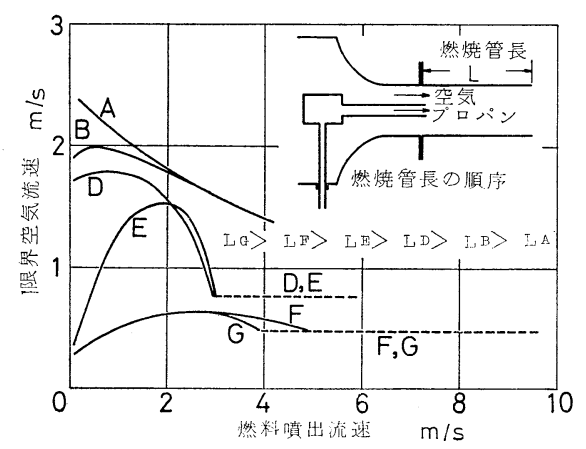

\section{図 1 気体燃料拡散炎の吹き消え限界の 1 例}

下側が安定である。実線部では吹き消えは吹きとびと 同時に起り, 破線部では浮き上り炎からの吹き消えが 起る。燃焼管長が長くなると振動燃焼が発生し易くな り, また発生すると振動はより激しいものになる。実 線部では燃焼管, 破線部では燃焼管 D, Eの各場合に 振動燃焼が発生していない。このときの吹き消え限界 に比して, 振動然焼が発生する場合の限界空気流速は 図に見られるように低下する。同様に2.1.4 で述べ た噴霧燃焼炎においても振動燃焼の発生による吹き消 え限界の低下現象が認められる。したがって, 燃焼装 置の自動化等を図るらえで操作のし易い安定な火炎を 得るためにも振動燃焼の発生を防止する必要がある。

\section{3. 騒音と振動燃焼}

燃焼装置から発生する騒音には送風機・モー夕等の 補機類から生じる騷音と燃焼炉本体から生じる騒音が あるが, 通常問題となるのは炉本体から発生する騒 音, とりわけ流れと燃焼の両過程に関連して生じる 騷音である。この騒音は乱流燃焼に伴う燃焼ごう音 (roar) と周期的不安定現象に由来する騒音とに大別 できる。
ごう音は乱流燃焼に伴う局所的な密度変動（体積変 動）により生じるランダム現象であり, 燃焼負荷と流 れの乱れ強さが大であるときほど著しい(6) とされてい る。したがって燃料・空気あるいは予混合気等の炉内 流入速度を小さくするとごう音レべルは急激に低下す る。また拡散炎に比して予混合炎の方がごう音レベル は高く7), 予混合炎について見ると予混合気濃度が然 燒速度最大のそれに近いほど著しいごう音が生じる。 また拡散炎ではごう音のかなりの部分が火炎基底部の おどりあるいはふらつきに由来するので, 超音波を浴 びせる等のそれを低減する方法の採用によりごう音レ ベルを下げ得るといら報告がある。

周期的不安定現象のらち間歇燃焼は一周期のうちに 燃焼の休止あるいはそれに近い状態の期間があり,っ いで急激な燃焼が生じて再び休止期間に入るという繰 り返しを行なっているもので, ごく低い周波数を有す る現象である。これに対し振動燃燒と火炎の振動は, 燃焼率が同様に変動するけれどもその低下期間を燃焼 の休止期間とは見なせない振動現象である。このうち 流体力学的不安定が燃焼過程の不安定をひき起す, い わば一方通行的な干渉様式をとる現象を火炎の振動と 呼び, 他方燃焼過程の不安定がさらに流れの不安定を 助長し, それが再び燃焼過程の不安定を増幅するとい うように流机過程と燃焼過程が相互に干涉し合って生 じる振動を振動燃焼と呼ぶ。かかる周期的不安定現象 にもとづく騒音は, その音圧スペクトルに顕著なピー ク周波数が現われる特徵があり,なかでも振動然焼に よる騒音が重要である。

通常の工業用燃燒装置では燃料流・空気流あるいは 予混合気流が比較的低速であるため, ごう音よりむし ろ振動燃燒による騒音が問題となり易い。そこで次章 では振動然焼をとりあげてもう少し詳しく議論する。

\section{4. 振動燃焼}

振動燃焼は元来多種多様な燃焼方式, 燃料種類ある いは燃㫩器形状のもとで発生するものであり, 多数の 報告が見られるロケット然桲器のほかジェットエンジ ン, ガスタービン燃焼器, ボイラ, トンネルバーナ, 熱風炉等の実用燃焼器および多数の実験規模の燃焼器 内でその発生が報告されている。したがって試行錯誤 的に燃料のとり替えや燃焼器やバーナの形状変更を行 なって見ても振動の発生防止は期し難い。たとえ防止 乙得たとしても時間と経費を浪費するし，またある装 置での経験を他の機会に十分生かすことができない。 むしろ振動の発生機構や振動の特性についてある程度 の明確な概念をもって取り組むのが望ましい。後に述 
べるようと振動燃焼は燃焼率の周期的変動によって励 起し，駆動される振動であるから，その変動原因を除 去する対策を講じることが抜本的な防止策であること は言うまでもない。しかし燃焜方式によってこの原因 は相違するものであるし，またある燃焼火炎に一つ以 上の原因が存在する場合さえあり得る。この点につい ては本誌上にる詳しい解説 ${ }^{899)}$ がある。ここでは主と して火炎そのものに変更を加えないで防止・抑制を図 る対策につき実例を示すことにし，最初にその原理を 知るために発振機構につき簡単に考え方を述べる。そ の際には音響振動のみに注目し, 他の型式の振動すな わちへルムホルツ型共鳴振動と非音響振動については 最後に若干の補足を付す程度にとどめる。なお音響振 動とは, 燃燒器の気柱共鳴振動数とほぼ同じ振動数を 示す振動のことである。

\section{1 音響振動の発振条件とその防止策}

いま $\omega=2 \pi(\gamma+i \delta)$ なる複素角振動数を考えて燃焼 器内の圧力 ・流速等が $e^{-i \omega t}$ 飞比例して変動するも のとする。このとき単位時間経過後に振幅は $e^{\check{\delta}}$ 倍に なるから， $\delta>0$ のとき振動は成長する。かかる成長 が最初微小なじょう乱から生じる場合を線型発振と言 う。この節で言う発振はこの線型発振である。発生す る圧力・速度等の変動は微小とし, 燃焼管は細長い形 状をしていて速度変動の起る方向は管軸 $x$ 方向である とする。また $x=0, \mathrm{~L}$ はそれぞれ燃焼器の入口と出口 であり，燃焼領域（火炎）は $x_{1} \leqq x \leqq x_{2}$ にあるとす る。さらに火炎は波長比して十分短いとし，火炎前 後の各領域内では位置によらず音速は一定とする。

このとき火炎前後の領域では基礎方程式から波動方 程式が導びかれ，これから $x=x_{j}(j=1,2)$ の各位 置での音響インピーダンス $Z j$ が次のように求められ る。

$$
\begin{aligned}
& Z_{j}=\rho_{j} a_{j} \tanh \phi_{j} ; \\
& \dot{\phi}_{1}=\frac{i \omega x_{1}}{a_{1}}-\phi_{0}, \quad \phi_{2}=\frac{i \omega\left(x_{2}-L\right)}{a_{2}}+\phi_{L}
\end{aligned}
$$

ここで $Z_{j}$ は圧力変動 $p_{j}^{\prime}$ と速度変動 $u_{j}^{\prime}$ の比で定義 され， $\phi_{j}$ の虚数部 $\theta_{j}$ は相対位置を表わすパラメー タで圧力の節と腹はそれぞれ $\theta=n \pi, \theta=\left(n+\frac{1}{2}\right) \pi$ $[n=0, \pm 1, \pm 2, \cdots]$ 飞相当し, $\left|Z_{j}\right|$ は $\theta=\left(n+\frac{1}{2}\right) \pi$ で最大, $\theta=n \pi$ で最小となる。 $\boldsymbol{\rho}$ は流体密度の時間平 均值, $a$ は音速, $\phi_{0}$ と $\phi_{L}$ はそれぞれ $x=0$ と $x=$ $L$ の位置の相対位置パラメータである。

一方燃焼領域内の質量, 運動量およびエネルギの保 存式は次のようになる。

$$
\begin{aligned}
& u_{2}^{\prime}=\frac{\bar{\rho}_{1}}{\bar{\rho}_{2}}|B| e^{i \varepsilon} u_{1}^{\prime} \\
& p_{2}^{\prime}=p_{1}^{\prime}=p^{\prime} \\
& q^{\prime}=\frac{A K}{K-1} \bar{p}\left(u_{2}^{\prime}-u_{1}^{\prime}\right)
\end{aligned}
$$

ここで $q^{\prime}$ は火炎で生じる燃焼率の変動量であり，K は断熱指数, $\bar{p}$ は圧力の時間平均值, $|B| \zeta \varepsilon$ は後 に述べる意味の火炎の応答性に相当するパラメータで ある。

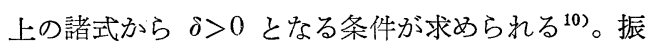
動エネルギの損失により生じる振動の減衰を無視する とその結果の一部は次のように表現することができ る。 $\varepsilon$ の值が $0>\varepsilon>(\pi / 2)$ であるような火炎では, 発振を起す次数の振動の圧力の腹は火炎の下流側に, また圧力の節は火炎の上流にある。 $\varepsilon$ の值が $0>\varepsilon>-$ $(\pi / 2)$ なる火炎では, 圧力の腹が火炎の上流側に, ま た圧力の節がその下流側となる振動次数のみが発振す る。四 2 にこの関係を図示した。この燃焼器はその入 口と出口が音響的にとれぞれ閉端および開端となって いる。例 $\mathrm{A}$ と例 $\mathrm{B}$ では燃燒器の等価長 $\left(\approx x_{1}+\frac{a_{1}}{a_{1}}(L-\right.$ $\left.\left.x_{1}\right)\right)$ が相違すると同時に火炎の相対位置 $\theta_{1}, \theta_{2}$ が互 いに異なる。そのため例 A では 1 次振動は $0>\varepsilon>-$ $(\pi / 2)$ なる火炎で, 2 次振動は $0<\varepsilon<(\pi / 2)$ なる火 炎で発生するに対し, 例 Bでは 1 次, 2 次の振動とも $0>\varepsilon>-(\pi / 2)$ なる火炎で発振する。

ここでパラメータ にの物理的意味を説明する。その 際に振動燃焼の励振機構についても説明を行う。式(2) は質量の保存式

$$
\begin{aligned}
& \bar{\rho}_{2} u_{2}^{\prime}=\bar{\rho}_{1} u_{1}^{\prime}-\int_{x_{1}}^{x_{2}}(\partial \rho / \partial t) d x \\
& =\bar{\rho}_{1}{ }^{\prime}\left(1-\frac{1}{\bar{\rho}_{1} u_{1}^{\prime}} \int_{x_{1}}^{x_{2}}(\partial \rho / \partial t) d x\right)
\end{aligned}
$$

を形式的に書きかえたものである。燃焼領域内で密度 変動 $(\partial \rho / \partial t)$ が生じなければ $x=x_{1}$ を通過して燃焼 領域に流入する流体質量と同量の流体質量 $\bar{\rho}_{2} u_{2}^{\prime}$ が同 時刻の単位時間内に $x=x_{2}$ を通して吐出される。実 際には $(\partial \rho / \partial t)>0$ の瞬間は燃焼領域に流入する流体 の一部が蓄えられ， $(\partial \rho / \partial t)<0$ の瞬間に 余分に吐出 されるので, 吐出量と流入量の振幅と位相は相違す る。にはと位相差である。ところで式(2)，(3)および 式(1)から次式が導びかれる。

$$
\frac{\bar{\rho}_{1}}{\bar{\rho}_{2}}|B| e^{\varepsilon i}=1+\frac{K-1}{A K p}\left(\frac{q^{\prime}}{u_{1}^{\prime}}\right)=1+\frac{K-1}{A K \bar{p}}\left(\frac{q^{\prime}}{p^{\prime}}\right) Z_{1}
$$

この式から位相ずれをは燃焼率の変動によってひき起 
例 $A$
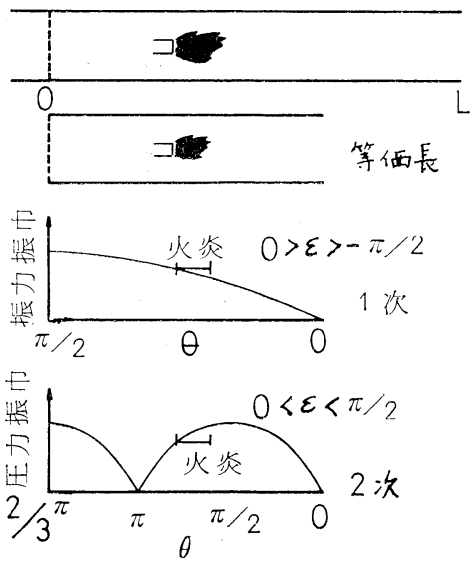

例 B
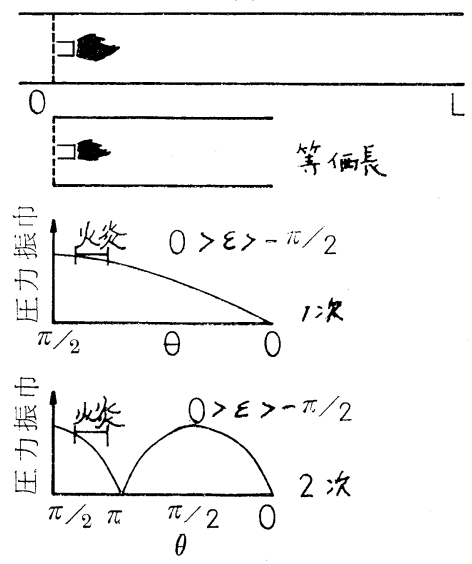

図 $2 \varepsilon$ の值亡発振次数の関係

されることがわかる。 $q^{\prime} \equiv 0$ のとき $\varepsilon=0$ であるが， $\varepsilon=0$ のときは発振しない。すなわち, 振動燃焼は燃 焼率の変動によってひき起されるということができ る。

振動の発振機構は燃焼領域内に仮想的なポンプがあ ると考えることによってより良く理解される。このポ ンプは前述のごとき密度変動に伴う周期的な流体の貯 蔵と余分な吐出を行なっている。このポンプが一周期 間に外部へ向ってする仕事量は次のようである。

$$
\begin{gathered}
W=\oint p^{\prime}\left(u_{2}^{\prime}-u_{1}^{\prime}\right) d t=\oint p^{\prime} u_{1}^{\prime}\left(\frac{\bar{\rho}_{1}}{\bar{\rho}_{2}}|B| e^{i s}-1\right) d t(6) \\
=\frac{K-1}{A K p} \oint \phi p^{\prime} q^{\prime} d t \quad(6)^{\prime}
\end{gathered}
$$

ここで積分は一周期間にわたって行なう。式 (6) は式 (4)を用いた変形式で，ポンプが燃焼率の変動に対応す る熱の出入りにより駆動される熱機関であることを示 している。式(6)は燃焼領域外の流体側から見ると, こ の流体が一周期間に受けとる振動エネルギである。 $W>0$ のとき流体が保持する振動エネルギは一周期ご とに増大し，これに伴って振幅が増大する。これはさ きほどの $\delta>0$ の条件の別の 表現であって Rayleigh の条件と呼ばれる。この条件と式 (6)' から再び振動然 熰が燃焼率の変動によって励起し, かつ駆動されるこ とがわかる。したがって $q^{\prime}$ の具体的な関数形がわか ればより詳しい発振限界の議論が可能であるが，その 関数形は各燃焼方式で相違するのでここではそのよう な検討は行わない。なお $q^{\prime}$ を実湘することは困難で あるが, 密度変動は主として温度変動によってもたら されているから，それを実測して $|B| ， \varepsilon$ を定めるこ
とは可能であり，さらにその值から式(5)により $q^{\prime}$ を 推定することは原理的に可能である。

さて燃焼器内で振動エネルギの損失が生じる場合に は, 式(6)による燃燒領域外の流体が受けとる振動エ木 ルギは一周期間に損失される振動エネルギ $E_{L}$ を上回 わるときにのみ発振が生じる。この場合の Rayleigh の条件は $W>E_{L}$ であり, これに対応して先の発振 条件は

$$
\delta>\delta^{*}(>0)
$$

となる。ここで $\delta^{*}$ はエネルギ損失に伴う振動減衰率 である。式(7)から推定される実際の発振条件の具体例 を概念的に図 3 に示した。この図の燃燒器は先の図の ものと同じであり，考える火炎は $0>\varepsilon>-(\pi / 2)$ な る特性を有するものとし，1次振動のみをとりあげ る。式(7)のウはさきほどの $\delta$ と同一であるが，それは $\sin \varepsilon \cdot \sin 2 \theta_{2}$ 飞比例する。燃焼率の変動が速度変動に 起因して生じる場合には $\sin \varepsilon$ の值は火炎の相対位置 によらず一定であるが, 燃焼率が圧力変動に起因して 変動に起因して変動する場合は火炎の相対位置により $\sin \varepsilon$ の值が変化し, 式(5)から推定されるようにその 絶対值は火炎が圧力の腹に近いほぼ大となる。このた め図の (i ) の場合には式(7)を満足する火炎の相対位 置範团は $\theta_{2}=\left(n+\frac{1}{4}\right) \pi$ に関して対称に分布するが, (ii) の場合にはそれは非対称で圧力の腹側にずれて いる。したがって, 図の (i) では $A, C$ の火炎位 置では発振しないが, $B$ の炎位置では発振し, また (ii) では $B, C$ の火炎位置では発振しないが，Aの 火炎位置では発振する。いずれの場合にも火炎が圧力 の腹および節のごく近傍に位置するときには発振し難 

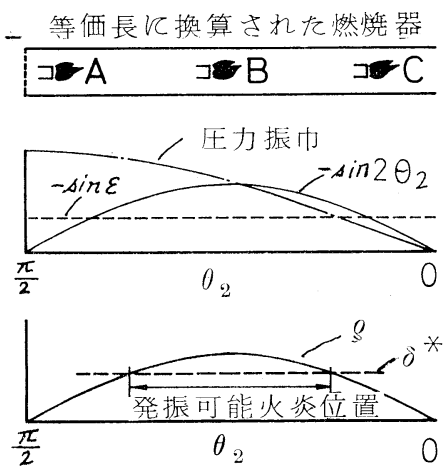

(i ) $q^{\prime}$ が速度変動により生じる場合
等価長江換算された燃媌器

$=A-\mathrm{A} B \mathrm{C}$
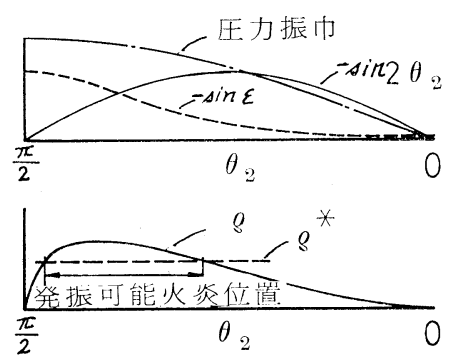

(ii ) $q^{\prime}$ が圧力変動により生じる場合

\section{図 3 火炎位置と発振の可否の例}

く, 発振を起さない火炎位置範囲は $\delta^{*}$ の值したがっ て振動エホルギ損失量が大であるほぞ広くなる。図 4 に空気霧化式バーナを用いた噴霧燃焼炎で生じる振動 燃燒についての観察例を示した。この図によると 1 次, 2 次振動ともに各振動次数の圧力の腹と節の近傍 に火炎が位置するとさには発振が生じないことが確か められる。また発振を生じる火炎位置範囲は圧力の腹 と節の中央に関してほぼ対称である。少なくとも圧力 の腹側にずれてはおらず, この火炎の燃椛率の変動が 速度変動に起因して生じていることを裏付けている。

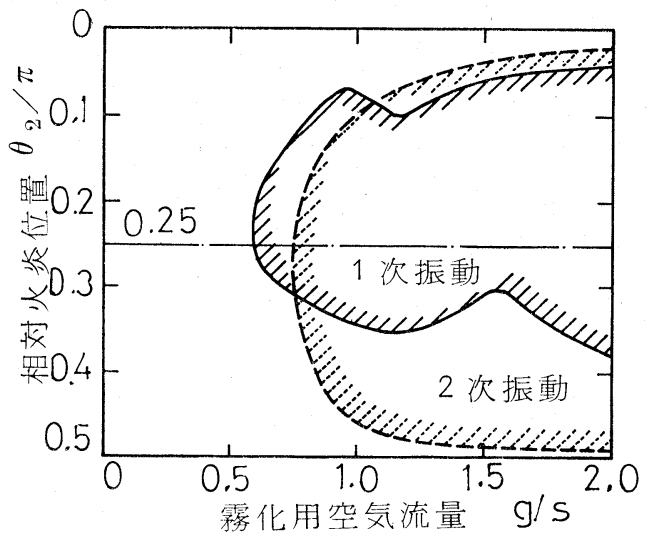

図 4 発振可能の火炎位置の実験例

以上述べたことから発振の防止策をとりまとめて見 ると次の 3 点に集約される。すなわち，(i ）〔が 0 に 近い火炎あるいは燃焼率が変動し難い火炎を実現する こと，（ii）火炎位置を適切化設定すること，(iii) $\delta^{*}$ の值すなわちエネルギ損失量を大とする工夫をするこ と，である。（i ）はすでに述べたように抜本的な対
策ではあるが，この対策を施すにはまず然㭠率の変動 機構の調査から始めねばならず，一朝一夕にして実現 できる対策ではない。応急の防止対策としては適して いない。（ii）の対策では, 原理的には低次の数次の 振動に対しては発振が起り難い位置に火炎を置くこと は可能である。一般に振動次数が高くなるほど振動工 ホルギの損失は大となるので, 実際高次の振動に多く の注意を払わないで済む場合がある。しかし，この対 策はバーナ位置あるいは燃料供給管や煙道等の寸法を 自由に変更できる装置においてのみ可能であり，また 燃焼装置の本来の目的を達成するらえに必要でない寸 法と形状の変更等の犠牲を払わなければならない。 （iii）の対策は比較的容易飞実現し得る方策である。 振動エネルギの損失は, 粘性散逸, 渦の発生, 固体壁 による吸收および放射等によって生じる。また流れの 運動方程式の非線型項の寄与を増大させるオリフィス 等の插入る振動エネルギ損失源として有効である。次 節でとりあげる振動の抑制対策はいずれる振動エネル ギの損失源としてやはり有効である。ただし, 振動工 ネルギの損失を増大させることは多くの場合, 燃烍器 内の平均流に対して圧力損失を増大させる結果を招 く。したがってこの対策の採用に伴って送風機の風圧 を上げることがしばしば必要となる。しかし，（i ）の 対策が早急に実現できない場合にはこれる止むを得な いであろう。

以上とりまとめた防止対策はとくに目新しいもので はない。かかる対策の説明に比して先立つ説明がやや 長過ぎたようにも思われるが，明確な指針をもって防 止対策を講じるらえで，またすでに工夫された諸対策 の原理を把握し，それを発展させるらえで，ある程度 の理念的理解は必要であろう。なおここで述べた考 
え方は最初の仮定のごとくごく単純な場合を想定して 導びかれたるのではあるが，これを燃焼器の横方向モ 一ドの振動や, 比較的長い火炎での振動等に適用する ことも可能である。しかしその際には，たとえば横方 向モードの振動では速度変動の生じる方向が平均流の 方向と相違しているから, 同じ振動数の軸方向モード の振動とは燃焼率の変動機構が同一でない可能性があ ること，また長い火炎では火炎各部の構造とその位置 の一波長中に占める相対位置が異るために各部が互い に効果を相殺し合って同じ燃料流量の短い火炎に比し て発振を起し難いこと等を別個に考慮する必要があ る。

\section{2 音響振動の抑制と振幅}

前節で述べた対策のいずれかを用いて発振が防止で きる場合には問題はないが，簡単に防止できない場合 には振幅を小さくして振動を抑制する必要がある。こ の節では, この目的のための数種の抑制対策について の実験例をまず示す。

図 5 は両端開放の火炎保持器を使用した予混合火炎 燃焼器内の 2 次振動を燃焼器のある箇所に一端を閉じ た分岐管を設けて抑制を図った例の結果である。騒音 レベルの測定例は位置 3 亿分岐管を設けたときの結果 である。 ${ }^{14)} こ の$ 結果から, 分岐管長が振動波長の約 (1) 4）のときに，分岐管径がより大きいときに効果的で あることがわかる。また別の実験例によると分岐管の 取付位置の影響に関しては，取付位置 $1,2 ， 3 ， 4$ の 間では抑制効果にたいした差異は見られないが，取付

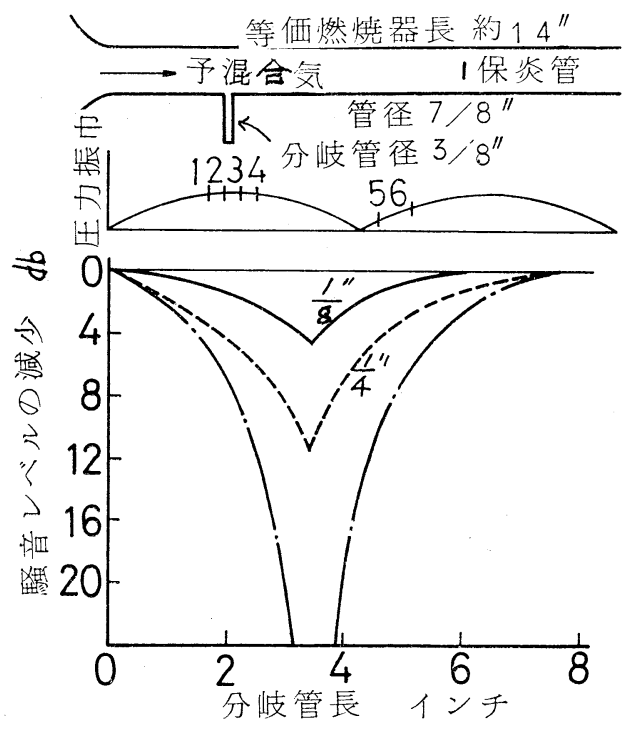

図 5 分岐管を用いた振動抑制例

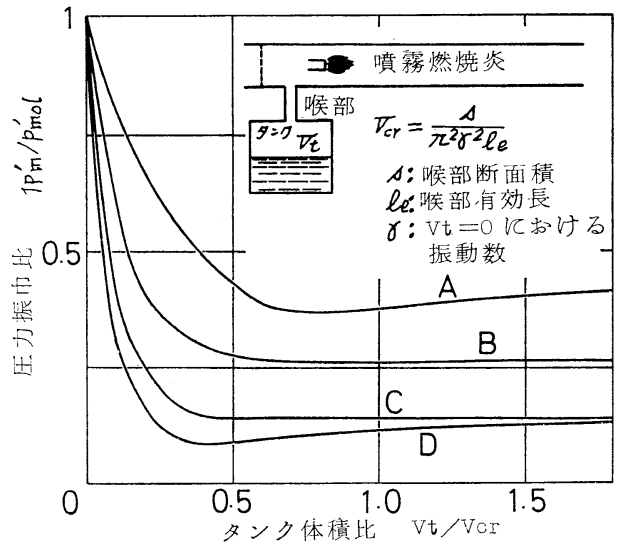

図 6 ヘルムホルツ共鳴器を用いた振動抑制例

位置を $3 \rightarrow 6 \rightarrow 5$ のように圧力の節に近ゔけると効果 が低減するようである。

図 6 は噴霧燃焼で生じる振動燃焼を燃燒器のある箇 所にヘルムホルツ共鳴器を付して抑制を図った例を示 す。然焼器および火炎とも図4 のものと同一であり, 図中 $A, B, C, D$ の区別は，それぞれが別の燃燒条 件の下で行われた実験例であることを示している。ま た, 縦軸はある一定位置で測定された燃焼器内の圧力 振幅を共鳴器を付さない場合の振幅で無次元化して示 してある。図によればタンク容積を増すと振幅は小さ くなり，抑制効果があることは明らかであるが， $V_{t}>$ $0.5 V_{c r}$ ではタンク容積を变えても抑制効果には著し い差異がない。振動エネルギ損失量を評価して見ると それは $V_{t}=V_{c r}$ でほぼ最大になる ${ }^{11) 。 し た か ゙ っ て, ~}$ 振動エネルギ損失量の大小のみを抑制効果の良否の唯 一の判定基準と見ることはできそうにない。とくに， 図に見られるように燃焼条件によって抑制効果が相違 するので, ある形状の共鳴器を取付けるときの抑制効 果がどの程度であるかを一般的に述べることは難かし い。なお共鳴器の取付位置は抑制効果に著しい影響を 与え, その位置が圧力の腹に近いほど有効である。こ の点は振動エネルギ損失量の評価結果と対応する。

図 7 は燃焼器壁に小孔を設けることにより抑制を図 った一例を示している。燃煳器と火炎はともに図 6 の ものに同じである。小孔の位置が圧力の腹に近づくと 抑制効果は增大するが，これも振動エネルギの損失量 の増大に対応している。前節で指摘したように振動工 ホルギ損失量があるレベル以上になると発振が防止さ れる結果が図に見られる。これは振動エネルギの損失 源としてヘルムホルツ共鳴器より小孔が必ずしも有効 

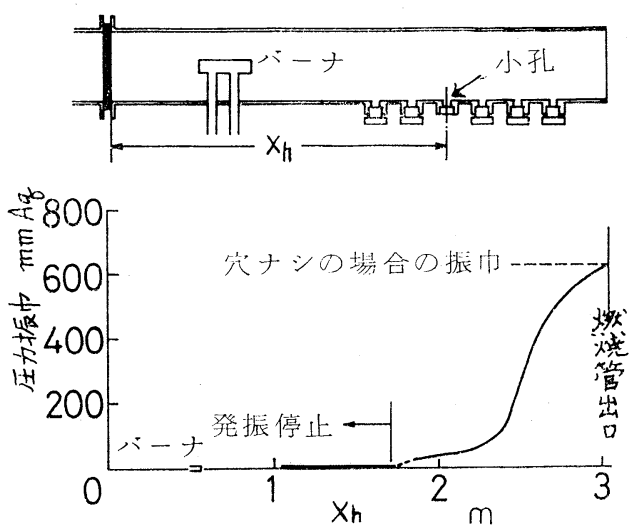

図 7 管壁にあけた小孔による振動抑制例

といらわけではなくて, 図 6,7 で互いに火炎位置が 相違しているためである。ちなみに，圧力の腹とバー ナの距離は図 6 で約 $1.4 \mathrm{~m}$, 図 7 で約 $0.6 \mathrm{~m}$ である。

以上の実験例はいずれも平均流の圧力損失に直接影 響を与えない方法で振動エネルギ損失量の増大を図っ たときのその効果を調べたものである。前節で指摘し たように，かかる対策は原理的には振動の防止対策と して有効であるはずのものであるが，実際には以上の 実験例のように対象とする火炎の $\varepsilon$ 值や火炎位置等 のいかんによって発振の防止までに至らない場合があ る。しかしここで重要なことはとのよらな場合にも この種の対策が少なくとも振幅の抑制対策として効果 を発揮する点である。振動の成長につれて振動エネル ギの損失量が増大し，また時には他方で然焼領域内の ポンプ仕事に由来する振動エネルギ伝達量が減少し, 両者が平衡する状態が我々が観察している振動状態で あることを考えれば, 振動エネルギ損失源を増すほど 振動振幅が小さくなるであろうことは容易に推定され る。したがって, 発振の防止が達成できないとして も, 許し得る限り振動エネルギ損失量の増大を図るこ とは振動を軽減するらえで良策であることは言うまで もない。しかし振動エネルギ損失量の大小のみをもっ て抑制効果の良否と判定することは前記のごとく常に 正確とは言い難い。これには主として二つの理由があ る。第 1 に定常に振動している状態は何らかの非線型 効果によってもたらされているから，これを非線型振 動論の立場から見なければならないが，この理論は抑 制効果の予測に役立つほど進展していない。たとえば 先の実験例に立ら返って見るならば，然焼条件による 抑制効果の差異が見られた。これは燃焼領域内の燃烧
率の変動量がその発生原因である速度変動ともはや線 型な関係にないと考えられるが，その関係が燃焼条件 によって相違しているためである。この点を扱うため には非線型振動論の観点が必要である。また，振動工 ホルギの損失量も非線型効果を含めて評価することは 種々の困難が伴ら。以上の理由に加わえて，第 2 に多 くの場合の振動波形は非周期成分を含んでいるから， 音圧スペクトル上のピーク周波数成分のみに注目する 考え方では正確を期し難いといら面がある。非周期成 分の影響も非線型振動論の進展に伴って検討されねば ならない。ともかく現状では抑制効果の正確な予想は 困難であり，実寸規模の然焼装置で効果を予備調査す ることが望ましい。

なお振動振幅は火炎の相対位置によっても変化す る。図 8 は図 4 の実験を行なった際の振動記録例から 振幅と火炎位置の関係をまとめた一例である。相異な

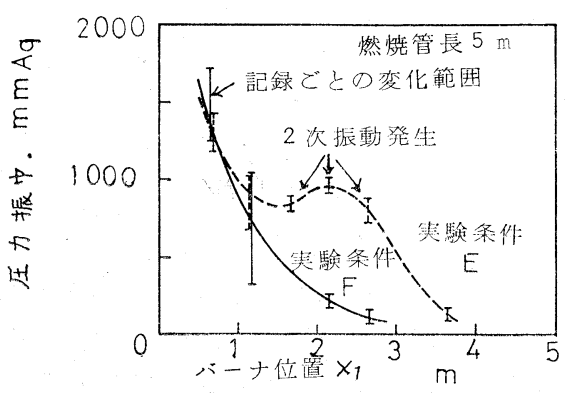

図 8 火炎の相対位置と振幅の関係の例

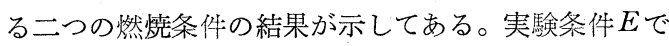
は 2 次振動の発生があって変化傾问は単純でないが, いずれの条件でも火炎位置が圧力の腹から遠ざかるに つれて振幅が小さくなっている。火炎の相対位置の変 更が可能な然焼装置では，火炎位置を圧力の節側へず らすことも振動軽減の一策である。同時に，他の防止 ・抑制策を施す場合に火炎の相対位置変化が伴ならと 予想されるときは，それによって圧力振幅がかえって 增大することがないよう注意を払う必要があることが 示唆される。

\section{3 その他の振動型式}

ここでは非音響振動とへルムホルツ共獡器型振動 (以下 HR 型振動と記す) について主として音響振動 と対比しつつ説明を加わえる。この種の振動は，管路 や弁類等の断面積縮小部と比較的大きな容積をもつ夕 ンク部からなる系で生じ，同一の系の音響振動に比べ て振動数がかなり低い。このらら，HR 型振動では夕 
ンク部が電気回路のコンデンサに，また断面縮小部は 電気回路のコイルに等価な作用を果しており, この振 動は電気的な C-L 回路の共振振動々類似している。 一方, 非音響振動は一般に HR 型振動よりさらに低周 波であって，断面縮小部がコイルではなく純抵抗と等 価な作用を果しており, 電気的な $\mathrm{C}-\mathrm{R}$ 回路の振動現 象に対比することができる。C-Ri 回路はそれ自体で は共振振動数を持たないから, 振動が起るとするとそ の振動数は振動を励起する原因の応答時間に主として 支配される。したがって非音響振動の振動数は燃焼率 変動を起す機構の特性時間と密接に関連している。こ のため振動数を測定すると逆に燃焼率の変動機構を調 查する手がかりとなる。この意味で非音響振動は防止 対策が講じ易い振動である。液体然料ロケットのChugging 等はその一例である。またボイラ等で生じる 場合もある ${ }^{122}$ 。

HR 型振動は大小各種のボイラ ${ }^{13)}$ でしばしば観察さ れる振動である。上述の $\mathrm{C}-\mathrm{L}$ 回路の共振振動数に対 応するへルムホルツ共鳴振動数は喉部の長さを $l$, そ の断面積を $S$, タンク容積を $V$ とすると

$$
\gamma=\frac{a}{2 \pi} \sqrt{\frac{S}{l V}}
$$

で与えられる。この振動では然焼器内で䚇㻎が一様に 同位相で変動しているので, 音響振動の場合に指摘し た火炎位犆の影響は現われない。振動数が同一燃焼器 の音響振動のそれに比して低いので, 音響振動の振動 数範囲で応答し得ないような緩慢な過程に関連した燃 焼率の変動機構により引き起される。たとえば，火炎 基底部のふらつきあるいは周期的な浮き上り，空気流
入速度の変化のあおりによる噴霧角の変化, 然料流入 量の変化等である。この型式の振動も, 音響振動の場 合と同じく振動エホルギ損失源を設けることによって 発振の防止，振動の軽減を図ることができる。しかし 振動数が低いため大きなエネルギ損失は期待し難く, また前節の分岐管等はかなりの大寸法になるので応用 乙難く実際に利用できる対策は限られていて困難な面 が多い。

\section{文献}

1) R. A. Strehlow, "Fundamentals of Combustion", Int. Textbook, p. 248 (1968)

2) D.S.Hacker, AIAA Journal, 12, 65 (1974)

3) 堀, 機論集, 33, 1993 (1967)

4) 鈴木ほか 3 名, 機論集, 40, 2262 (1974)

5) 鈴木ほか 3 名, 機論集， 41，43 (1975)

6) R. D. Gimmar \& A. A. Outnam, Comb. \& Flame, 18, 435 (1972)

7) T.M. Sudgen, 筧 8 回燃焼シンポジウム特別講演 要旨 (1970)

8) 辻, 燃焼誌, 50, 778 (1971)

9) 竹野, 燃協誌, 50, 785 (1971)

10）佐藤, 鈴木, 機論集, 33，1260（1967）

11）鈴木, 若園, 機講論集, No.710-14, 257(1971)

12) M. Thring, Proc. 7th Int. Symy. Comb., Butterworths., 659 (1959)

13) F. Mauss and others, Proc. 10th Int. Symp. Comb., Comb. Inst., 1241 (1965)

(14) A. A. Putnam, Combustion-Driven Oscilla tions in Industry, Elsevier, p. 159 (1971)

\title{
Unstable Phenomena of Flame and Gombustion Noise
}

\author{
by Kenjiro Suzuki \\ (Kyoto Univ.)
}

\begin{abstract}
SYNOSISS :-Among others, blow-out of flame and oscillatory combustion are important unstable phenomena of flame. In the first place of this article, it is pointed out that the blow-out limit is remarkably affected by the occurrence of oscillatory combustionafter some typical examples of blow-out are mentioned about. The second part of this article deals with combustion noise. Since the oscillatory combustion is the main cause of combustion noise, it is separately discussed in the last part of this paper. Firstly, a simple theory is presented regarding how the oscillation can be self-excited. From its view point, an explanation is given as to why some proposed measures are efficient to suppress the oscillation. Secondly, Some examples of method milding the oscillation are presented.
\end{abstract}

